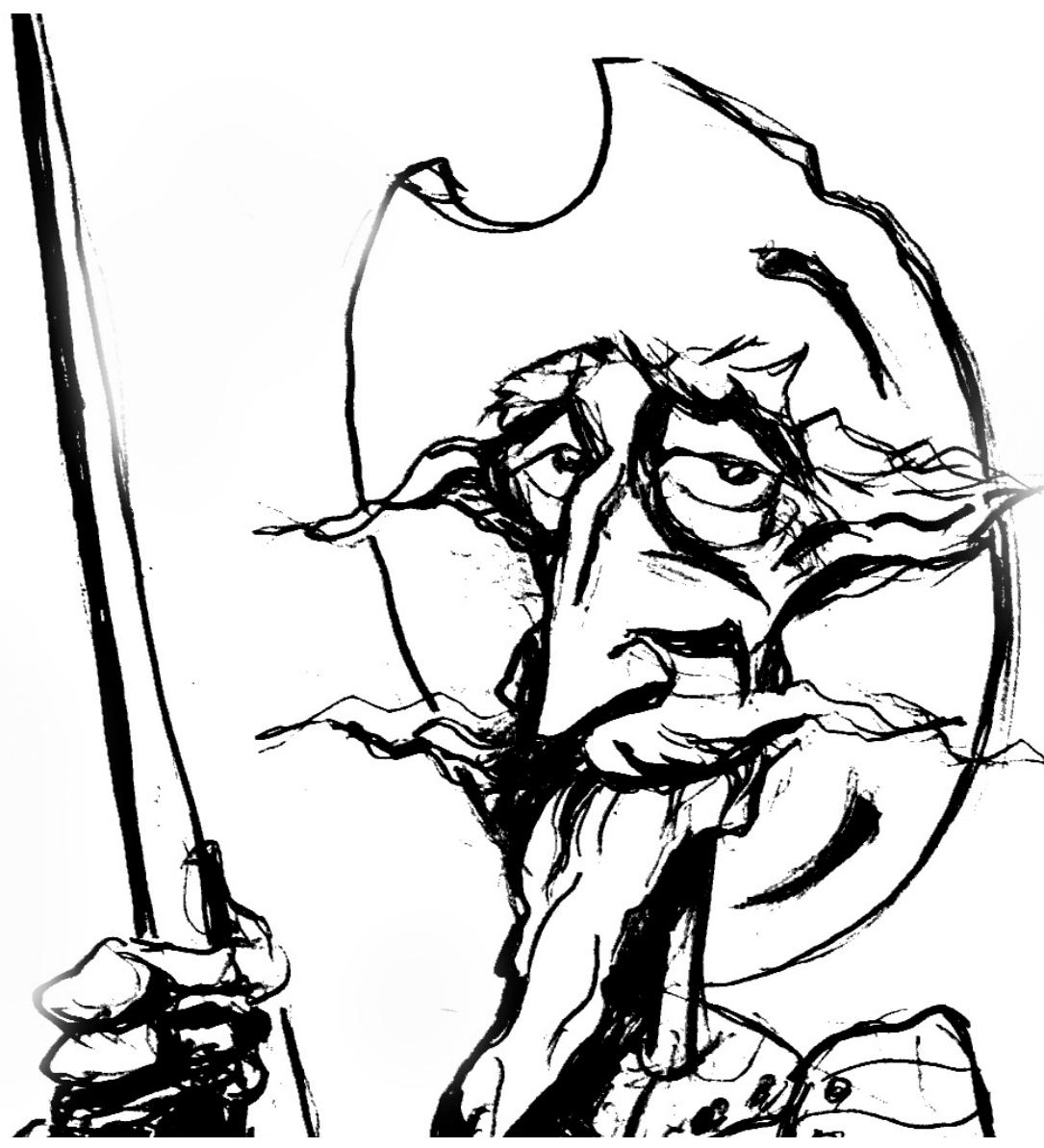

A la conquista espiritual de la "Tierra Magallánica". Los jesuitas del Paraguay y la Ciudad de los Césares en el siglo XVIII

[Fabián R. Vega] 



\title{
A la conquista espiritual de la "Tierra Magallánica". Los jesuitas del Paraguay y la Ciudad de los Césares en el siglo XVIII*
}

\author{
The Quest for the Spiritual Conquest of the "Magellanian Land". The Jesuits \\ of Paraguay and the City of the Caesars during the $18^{\text {th }}$ Century
}

FABIÁN R. VEGA

\section{Resumen}

En este artículo analizamos las exploraciones geográficas y la producción textual de la Provincia Jesuítica del Paraguay relacionadas con la Ciudad de los Césares durante el siglo XVIII. Estudiamos la ambivalencia de la creencia jesuítica en esta ciudad a mediados del siglo XVIII, algunos textos pragmáticos destinados a manipular a las autoridades y la relación entre la Ciudad de los Césares y el proyecto para la "conquista espiritual" de la población indígena de la Patagonia meridional. Finalmente, exploramos los cambios en la escritura jesuítica relativa a esta ciudad durante las décadas finales del siglo.

\section{Palabras clave}

Ciudad de los Césares; Jesuitas; Patagonia; Geografías Imaginarias; Escepticismo.

\begin{abstract}
In this article we analyze the geographical explorations and textual production of the Jesuit Province of Paraguay related to the City of the Caesars during the $18^{\text {th }}$ century. We study the ambivalence of the Jesuit belief in this city in the mid-18 $8^{\text {th }}$ century, some pragmatic texts aimed at manipulating the authorities and the relationship between the City of the Caesars and the project for the "spiritual conquest" of the Indigenous population of southern Patagonia. Finally, we explore the changes in the Jesuit writing concerning this city during the last decades of the century.
\end{abstract}

Keywords

City of the Caesars; Jesuits; Patagonia; Imaginary Geographies; Skepticism.

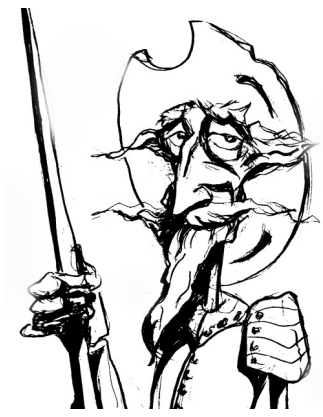

Recibido con pedido de publicación el 12 de marzo de 2020

Aceptado para su publicación el 15 de mayo de 2020

Versión definitiva recibida el 3 de julio de 2020

Fabián R. Vega, Consejo Nacional de Investigaciones Científicas y Técnicas, Instituto de Altos Estudios Sociales, Universidad Nacional de San Martín, Universidad de Buenos Aires, Buenos Aires, Argentina; email: vegafabianr@gmail.com

* Agradezco los comentarios de los árbitros anónimos de la revista.

Esta obra se publica bajo licencia Creative Commons. Atribución-NoComercial-CompartirIgual (cc)) EY-NC-sA 4.0 Internacional

Vega, Fabián R. “A la conquista espiritual de la 'Tierra Magallánica'. Los jesuitas del Paraguay y la Ciudad de los Césares en el siglo XVIII”, Prohistoria, Año XXIII, núm. 34, dic. 2020, pp. 159-189. 
Entre los siglos XVI y XVIII, distintos sectores de la sociedad colonial de Chile y el Río de la Plata llevaron adelante expediciones hacia los territorios más australes de Sudamérica. Algunos de estos viajes tenían como objetivo explícito hallar la Ciudad de los Césares, una ciudad imaginaria ubicada en la Patagonia, bien en el Estrecho de Magallanes o bien en las estribaciones de la cordillera de los Andes. La creencia en esta ciudad se originó en el siglo XVI y aunque los componentes de la misma variaron según los rumores y las versiones, muchas veces incluyeron la presencia de población blanca (de origen europeo o simplemente cristiana) y gran cantidad de riquezas bajo la forma de metales preciosos.

En una experiencia relativamente poco conocida, durante el siglo XVIII algunos jesuitas de la provincia del Paraguay realizaron exploraciones en búsqueda de esta ciudad y escribieron varios textos al respecto. El objetivo principal del artículo es examinar esta experiencia desde la perspectiva de la historia cultural. Especialmente, pretendemos evaluar el grado de la creencia de los misioneros en la Ciudad de los Césares, para lo cual estudiamos los argumentos presentados respecto a la existencia de la ciudad, la circulación de informaciones impresas y manuscritas y la evolución de las ideas a lo largo de la centuria. Las preguntas que intentamos responder son: ¿qué naturaleza tuvieron las representaciones de los jesuitas del Paraguay sobre la Ciudad de los Césares?, ¿en los textos escritos por los jesuitas se identifica una creencia en la existencia de la ciudad o más bien cierta incredulidad?, ¿en qué fuentes orales y textuales se basaron y cuáles son los argumentos postulados en ellas para sostener su creencia o desmentirla?, ¿se percibe algún tipo de evolución en cuanto a estas ideas?

Nuestro argumento central es que, aunque en los textos de los jesuitas del Paraguay predominó cierto escepticismo e incredulidad respecto de la existencia de la Ciudad de los Césares, los miembros de la Compañía no abandonaron la posibilidad de presentar afirmaciones crédulas como estrategia retórica de manipulación de las autoridades políticas. En este sentido, indicamos que por lo menos algunos textos jesuíticos pusieron en juego performances argumentales determinadas por el pragmatismo. Al mismo tiempo, sostenemos la existencia de una amplia producción textual jesuítica sobre la Ciudad de los Césares. Esta producción fue independiente de las intenciones de manipulación y da cuenta de una gran confianza en la apertura de la población indígena del extremo meridional de la Patagonia -en particular del Estrecho de Magallanes- a la evangelización. Postulamos que los rasgos atribuidos a esta población indígena derivan de las características de los 
presuntos habitantes de la Ciudad de los Césares -blancos, pacíficos, cercanos al cristianismo- y conforman un equívoco que tiene una larga tradición en la constelación discursiva sobre esta ciudad. Desde este punto de vista, la creencia en la Ciudad de los Césares sirvió a los jesuitas para conocer (y al mismo tiempo inventar) las características etnográficas de la población indígena que pretendían evangelizar en su "conquista espiritual" de la "Tierra Magallánica". ${ }^{1}$ Como veremos a continuación, esta creencia con que los jesuitas dialogaron había nacido durante el inicio de la ocupación europea del Río de la Plata y se había consolidado a todo lo largo de la época colonial.

\section{Una ciudad imaginaria en el extremo sur}

Las geografías imaginarias -en cuya estela se inscribe la Ciudad de los Césaresconstituyen un problema de especial importancia para la historia cultural de la modernidad temprana y de la expansión oceánica. Aunque este tipo de creencias se remonta a la Antigüedad y la Edad Media, el "descubrimiento" del Nuevo Mundo por parte de los europeos multiplicó la circulación de estas representaciones y habilitó su localización en las regiones de América que (todavía) no conocían. En este sentido, las geografías imaginarias del "Nuevo Mundo" pueden entenderse a la vez como una forma de lidiar con el asombro ante lo desconocido y como una posible inscripción de las novedades geográficas en los conocimientos del pasado (Grafton, Shelford, \& Siraisi, 1995; Greenblatt, 1991). La representación edénica de la naturaleza y la geografía americanas guió por lo menos en parte la ocupación espacial del Nuevo Mundo (Buarque de Holanda, 1996 [1959]) y, entre los exploradores y conquistadores, fue especialmente el ansia de metales preciosos lo que disparó la búsqueda de sitios poblados de riquezas como El Dorado, el Lago Parima, Cíbola, Manoa, Patití, Trapalanda o la Ciudad de los Césares (Barcelos, 2013: 19-20 y 498).

Como lo ha señalado Jean Pierre Sanchez, el imaginario condicionó el intento por alcanzar este tipo de lugares y fue uno de los factores que impulsaron la expansión europea en América (Sanchez, 1996: 13-23). Por esa razón, constituye un aspecto relevante para el estudio de las relaciones entre los europeos y las poblaciones amerindias. Las primeras referencias y expediciones a estos sitios datan de comienzos del siglo XVI, pero es evidente que los viajes determinados por las geografías imaginarias se sostuvieron (y a veces se

\footnotetext{
${ }^{1}$ En términos metodológicos, consideramos la creencia en la Ciudad de los Césares como una "representación" (en el sentido de Chartier, 1992, 1996). Las representaciones son objetos materiales -cartas, relaciones, mapas, imágenes, etc.- que poseen una faceta "transitiva" y otra "reflexiva". El componente "transitivo" señala una ausencia, algo que está fuera de la representación, un referente: en este caso, la Ciudad de los Césares. El componente "reflexivo" implica que las representaciones producen efectos y poseen poderes por sí mismas, por hacer presentes esos referentes a los que aluden. Estas representaciones cuentan con un circuito preciso de producción, circulación y recepción.
} 
multiplicaron) en el siglo XVIII. Sin embargo, la investigación ha tendido a privilegiar las dos centurias previas. Al poner el foco en un caso específico de producción textual sobre la Ciudad de los Césares en el siglo XVIII, uno de los propósitos subyacentes de este artículo es restablecer la relevancia de las geografías imaginarias americanas en esta centuria.

Los historiadores y académicos han analizado los viajes en busca de la Ciudad de los Césares, los rumores en torno a la misma y algunos textos que se escribieron respecto de esta ciudad (Ainsa, 1992; Estellé \& Coudyoudmjian, 1968; Gandía, 1933, 1946; Urbina C., 2017: 26-33). Silvia Tieffemberg reconstruyó los "cuatro relatos previos" que originaron la "constelación discursiva" de la Ciudad de los Césares (Tieffemberg, 2015), mientras que Jean Pierre Sanchez compiló los detalles de las distintas versiones (Sanchez, 1996: 729-762). El primer relato corresponde a la narración oral de Francisco César, un soldado integrante de la expedición de Sebastián Caboto (†1557) al Río de la Plata que partió en una exploración hasta las sierras de Córdoba (actualmente Argentina) desde el fuerte de Sancti Spiritu, instalado en los márgenes del río Paraná hacia 1527. César relató haber hallado una ciudad indígena gobernada por un "gran señor" y describió la presencia de oro y plata. Su relato fue posteriormente incluido en La Argentina de Ruy Díaz de Guzmán (†1629) (Tieffemberg, 2015: 18-19), un texto de amplia circulación manuscrita en la época colonial. Existe consenso en la investigación especializada respecto de que el relato de César es tanto la primera referencia a esta ciudad como el origen de su nombre.

La segunda versión deriva de la huida de población indígena de ascendencia incaica hacia el sur. Según Tieffemberg, esta se originó en una expedición del conquistador Diego de Almagro (1475-1538) en 1535 que alcanzó la ubicación de la actual ciudad de Santiago del Estero (Argentina). Una población de mitimaes incaicos allí asentada, tras una refriega con el grupo de Almagro, habría escapado hacia el sur cargando grandes tesoros. En 1586, el gobernador de Tucumán Juan Ramírez de Velasco (1539-1597) justificó una expedición hacia el sur en una carta al rey Felipe II aludiendo a una provincia "que llaman los Césares" en la que "hay gran suma de gente" y "grandes riquezas de oro" (Tieffemberg, 2015, p. 19). La tercera versión se originó en 1598, cuando los españoles de Chile fueron derrotados por los araucanos y abandonaron sus posiciones al sur del río Biobío. A partir de este hecho, circularon rumores de que un grupo de españoles había huido hacia el sur con sus tesoros (Tieffemberg, 2015: 20-21).

Una cuarta y última vertiente de los relatos sobre los Césares, más importante para nuestra investigación, se basó en las narraciones de los sobrevivientes de varios naufragios en el Estrecho de Magallanes (Tieffemberg, 2015: 21-24). El naufragio más comentado en el siglo XVIII con relación a la Ciudad de los Césares era el de dos naves que formaban parte de una expedición marítima que pretendía llegar a las Islas Molucas, financiada por el 
obispo de Plasencia Gutierre de Vargas Caravajal (1506-1559) y que partió de Sevilla en 1539. Aunque nada se supo entonces de los náufragos, en 1563 dos personas se presentaron en Concepción (actualmente región del Biobío, Chile) declarando ser sobrevivientes de la expedición. Dos relaciones manuscritas relataron estos hechos; en ellas se indica que gran parte de la tripulación sobrevivió al naufragio y se internó tierra adentro, donde encontraron población indígena con rasgos físicos peculiares (se habla de un indígena "corpulento y blanco") y una ciudad con, entre otras cosas, "multitud de oficiales plateros con obras de vasijas de plata" (Tieffemberg, 2015, p. 22). De acuerdo a Estellé y Coudyoudmjian, esta expedición “terminó por gestar la existencia de la misteriosa ciudad" (Estellé \& Coudyoudmjian, 1968, p. 285), mientras que en la interpretación de Sanchez los distintos naufragios fueron los factores que trasladaron definitivamente la ubicación imaginaria de la ciudad hacia el sur (Sanchez, 1996: 729-762), otorgándole así uno de sus rasgos más distintivos.

En el siglo XVI quedaron establecidos los componentes asociados a la riqueza, la población blanca o incluso el origen hispánico de la ciudad; en el XVIII aparecieron los relatos que aludían a grandes templos de piedra, la templanza y moderación del clima y la inexistencia de enfermedades (ver por ejemplo el relato incluido en De Angelis, 1836: 3-10), componentes que forman parte de representaciones edénicas muy extendidas sobre el Nuevo Mundo (Buarque de Holanda, 1996 [1959]: 185-258). Estellé y Coudyoudmjian han mostrado que, durante la segunda mitad del siglo XVII y el siglo XVIII, rumores impulsados por navegantes o informantes indígenas reactivaban periódicamente en el Río de la Plata y en Chile el interés por la ciudad (Estellé \& Coudyoudmjian, 1968: 286-300). En ocasiones, las autoridades coloniales respondían enviando una expedición, tal vez por el temor de que existieran colonos ingleses $\mathrm{u}$ holandeses apoderándose de territorios australes. En efecto, según estos investigadores la "curiosidad" de las autoridades "no estaba exenta de prudentes considerandos de índole militar", sobre todo cuando los testigos indicaban que "estos Césares blancos no hablaban castellano" (Estellé \& Coudyoudmjian, 1968, p. 296). A manera de ejemplo, en 1791 una fragata recibió orden del virrey de Perú de vigilar la existencia de pescadores extranjeros en la costa sur de Sudamérica. El gobernador de Chile escribió al rey, a partir de esta exploración, que también podría ser útil para obtener "alguna luz de los decantados Césares, bien sea como se figuran españoles escondidos o extranjeros poblados" (Estellé \& Coudyoudmjian, 1968, p. 298). ${ }^{2}$

\footnotetext{
2 Cabe destacar que algunas interpretaciones recientes sugieren posibles orígenes indígenas de la creencia (Martinic B., 2007). Ciertamente las poblaciones indígenas patagónicas cumplieron un rol fundamental en las informaciones que guiaron las exploraciones, así como también en sus malentendidos. No deberían descartarse apuestas intencionales en este último plano.
} 
Al mismo tiempo que esto sucedía, las órdenes religiosas especializadas en tareas de evangelización no eran ajenas ni a las búsquedas de la ciudad ni a la producción de textos en torno a la misma. Se conocen los viajes efectuados por los jesuitas desde Chile y especialmente la figura de Nicolás Mascardi, a quien aludiremos a continuación (Acuña, 2012, 2014; Furlong, 1963; Urbina C., 2020). Algunos franciscanos, como Pedro Jerónimo de la Cruz y Francisco Menéndez, también participaron en exploraciones en busca de los Césares (Gandía, 1946: 257-270). Para el caso de la provincia jesuítica del Paraguay, algunos documentos sobre la ciudad fueron recopilados y publicados por el intelectual Pedro de Angelis (1784-1859) en 1836. ${ }^{3}$ Sin embargo, si exceptuamos el reciente trabajo de Artur H. Barcelos -quien analizó las búsquedas de geografías imaginarias por parte de distintos jesuitas en América en varias secciones de su tesis doctoral (Barcelos, 2013: 57-97, 309-342 y 498-522)-, la experiencia de los misioneros jesuitas del Paraguay con respecto a la Ciudad de los Césares permanece en gran parte ignorada. En la siguiente sección, presentamos brevemente la búsqueda jesuítica de la Ciudad de los Césares desde Chile durante el siglo XVII, que constituye el preámbulo necesario de la producción textual jesuítica del Paraguay respecto de esta creencia.

\section{Creencia y búsqueda jesuítica de la Ciudad de los Césares en el siglo XVII}

Varias de las expediciones y viajes de los jesuitas se realizaron desde Chile, viceprovincia dependiente de la provincia de Perú de la Compañía de Jesús hasta 1683 y provincia independiente a partir de entonces. Estos viajes tuvieron como base el colegio de Chiloé, isla que cumplía la función de vigilar la costa meridional de Sudamérica para Chile (Urbina C., 2013) y desde la cual los misioneros también llevaron adelante intentos más o menos fracasados por reducir a la población indígena. A menudo las tentativas de evangelización y la búsqueda de la Ciudad de los Césares fueron parte de un mismo proyecto, probablemente porque la creencia estaba muy instalada en el territorio chileno y en particular chiloense (Acuña, 2012, 2014; Barcelos, 2013: 309-312; Nicoletti, 2004; Urbina C., 2020). Los jesuitas de Chile ya se habían referido a la ciudad en textos de la primera mitad del siglo XVII. Alonso de Ovalle (1601-1651) indicó en Histórica relación del Reyno de Chile (Roma, 1646) que "hay noticias muy recibidas de que la tierra adentro de Chile hacia el estrecho, hay una Nación, que llaman los Césares" (Ovalle, 1646, p. 72), nación presuntamente originada en el naufragio de la expedición financiada por el obispo de Plasencia en 15391540. En este texto, Ovalle también mencionó detalles de la creencia, como la

\footnotetext{
${ }^{3}$ Pedro de Angelis incluyó los documentos en uno de los volúmenes de su Colección de obras y documentos relativos a la historia antigua y moderna de las provincias del Río de la Plata. Esta colección contiene una gran cantidad de producciones jesuíticas, que De Angelis valoraba por el aporte que significaban para los conocimientos geográficos de la naciente Confederación Argentina (Perrone, 2019).
} 
población blanca, la presencia de campanas y la riqueza mineral, e incorporó la noticia de un presunto contacto con los habitantes por parte de un jesuita. Aunque la ciudad no está representada en la "Tabula Geographica Regni Chile" que se encuentra normalmente al final del libro de Ovalle, existen versiones extendidas de este mapa que poseen la representación (véase Imagen 1). A partir de esta información, cartógrafos como Nicolas Sanson (1600-1667) y Guillaume Delisle (1675-1726) ubicaron también con precisión la Ciudad de los Césares en sus mapas "Le Paraguayr, le Chili, la Terre et les Isles Magallanicques" (1656) (véase Imagen 2) y "Carte du Paraguay, du Chili, du Detroit de Magellan" (1703).

\section{Imagen 1}

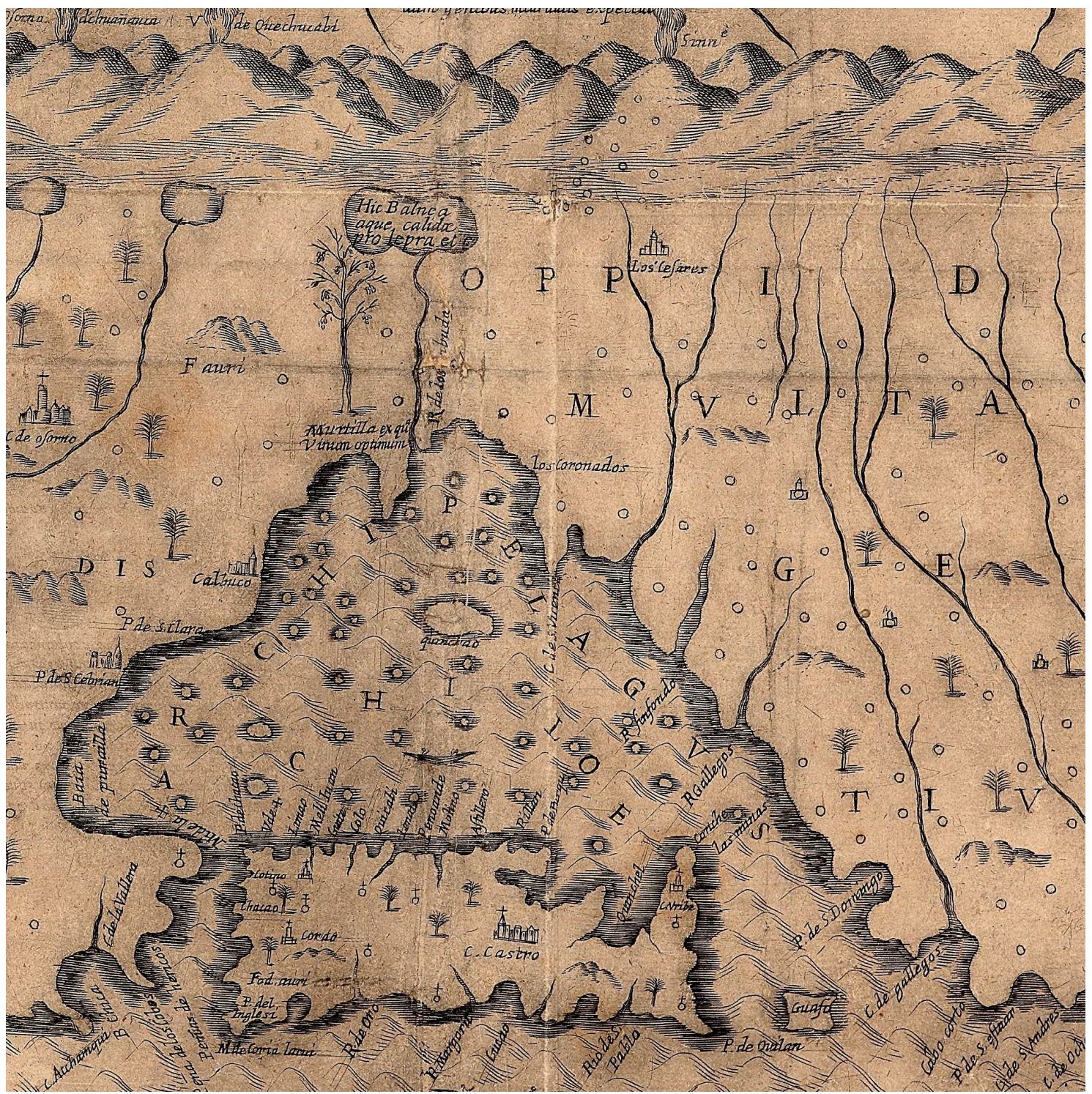

Detalle del mapa "Tabula Geographica Regni Chile”, con ubicación de la Ciudad de los Césares. Mapa digitalizado por John Carter Brown Library (JCB Map Collection, 11250-1). 


\section{Imagen 2}

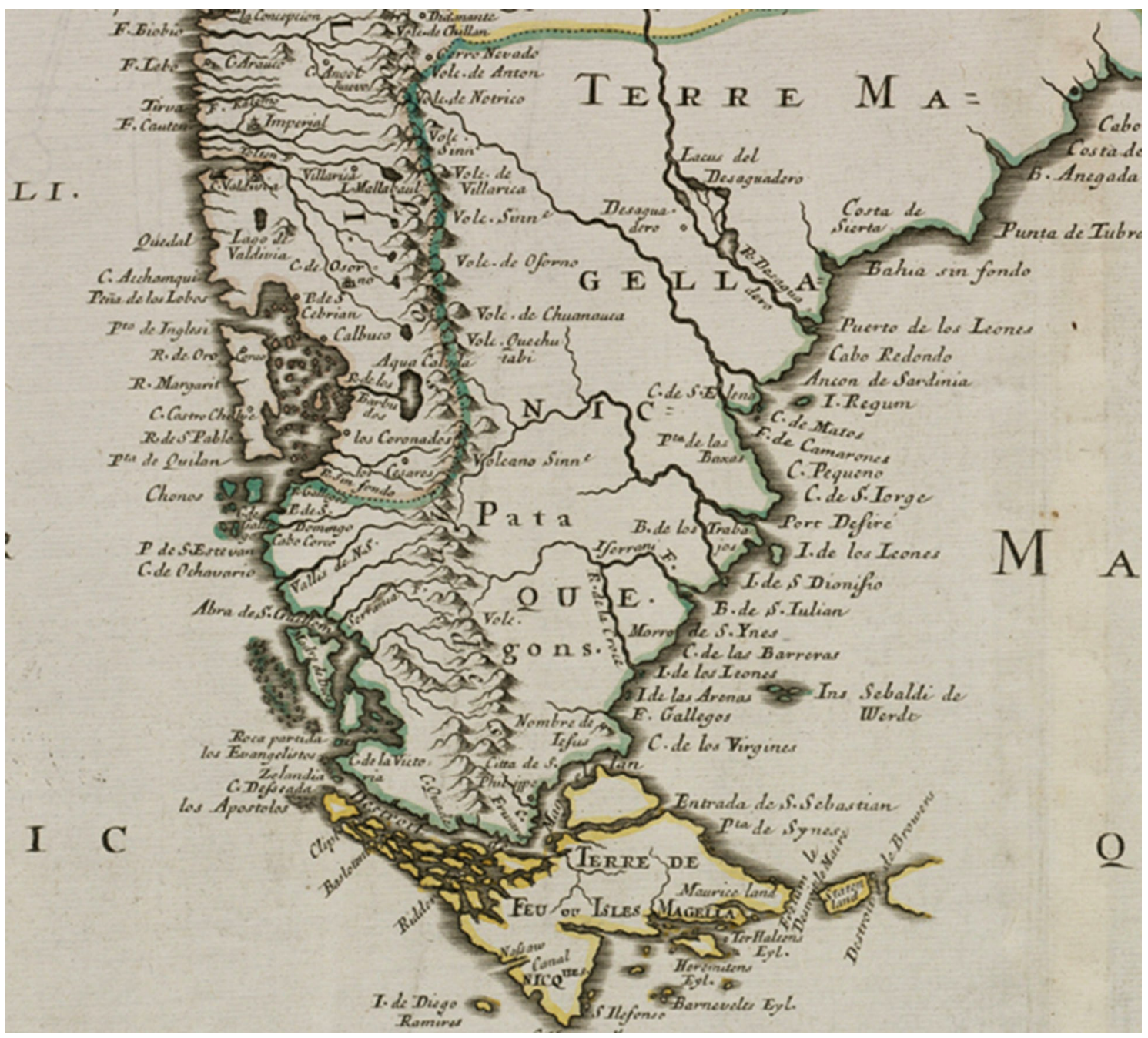

Detalle del mapa “Le Paraguayr, le Chili, la Terre et les Isles Magallaniques" de Nicolas Sanson. Mapa digitalizado por Norman B. Leventhal Map Center (Boston Public Library).

En Chile, una figura se destacó por su insistencia en afirmar la existencia de la Ciudad de los Césares, Nicolás Mascardi (1624-1673). Este jesuita nació en Sarzana, en la península itálica (actualmente región de Liguria) y estudió en Roma con el famoso polígrafo Athanasius Kircher (†1680), con quien mantuvo correspondencia a lo largo de su vida y de quien se convirtió en un importante informante (Acuña, 2012; Urbina C., 2020). Llegó a Chile en 1651 y con el tiempo se convirtió en rector del mencionado colegio de Chiloé. A fines de la década de 1660 comenzó a misionar con la población indígena circundante al Lago Nahuel Huapi (actualmente provincias de Neuquén y Río Negro, Argentina). Desde esa base, realizó viajes hacia el sur intentando alcanzar el estrecho de Magallanes y la Ciudad de los Césares. Mascardi estaba tan convencido de la existencia de esta ciudad que creyó posible comunicarse con sus habitantes a través de correspondencia, puesto que envió cartas en español, 
latín, hebreo, italiano, griego y poya intentando contactarlos (Acuña, 2014, p. 49). Incluso reveló sus intenciones a la población indígena local, como lo manifiesta en una carta relatoria de 1670: “[D]espués de bautizados les di a entender cómo yo tenía mucha lástima de aquellos españoles, que se habían perdido, ochenta años hacía y se habían poblado en esa frontera del mar oriental y estaban ya sin sacerdote que les perdonase sus pecados y enseñase la doctrina cristiana" (Furlong, 1963, p. 126).

Claudia Acuña indicó que la labor misionera de Mascardi estaba inscripta en un "imaginario barroco" constituido por epigramas, emblemas, símbolos y jeroglíficos -derivado en parte de su contacto con Kircher- que dio lugar a un "método místico" y a una específica valoración del ascetismo y la santidad (Acuña, 2012, 2014). Al mismo tiempo, Urbina C. (2020) resaltó que su creencia era compartida por gran parte de la sociedad colonial chilena, incluyendo las autoridades y otros jesuitas, y que no debería estar asociada a una credulidad particular del italiano. En cualquier caso, en 1671 Mascardi escribió proféticamente a Kircher que se sentía "infaliblemente destinado a humedecer con mi sangre la ardiente sed" de los "bárbaros" indígenas de la Patagonia (Acuña, 2014, p. 49). Dos años más tarde fue asesinado por la población local y se convirtió en un mártir, una figura cuyo comportamiento debía ser valorado y emulado por otros misioneros. Probablemente el hecho de que un mártir estuviese tan convencido de la existencia de la Ciudad de los Césares estimuló el interés de jesuitas posteriores por su búsqueda. Después de Mascardi, otros misioneros de Chile continuaron el proyecto de evangelización en torno al Nahuel Huapi (hasta 1717) y la búsqueda de la Ciudad de los Césares, con resultados igual de infructuosos. Al mismo tiempo, comenzaron a desarrollarse las expediciones y la producción textual de los jesuitas del Paraguay. Aunque estos conocían los textos de Mascardi -y el imaginario de que este estaba imbuido-, su búsqueda constituye un fenómeno autónomo y diferenciado.

\section{Los jesuitas del Paraguay en la primera mitad del siglo XVIII y su ¿creencia? en la Ciudad de los Césares}

\section{Creencia y performance}

Los jesuitas del Paraguay son especialmente conocidos por su labor de evangelización entre los indios guaraníes, iniciada a comienzos del siglo XVII (Wilde, 2009). Sin embargo, desde fines de dicha centuria los misioneros empezaron a ampliar su acción evangelizadora a otros espacios como el Chaco y Chiquitos (actualmente Bolivia) y, al promediar el siglo XVIII, establecieron las primeras reducciones en el sur de la actual provincia de Buenos Aires (Arias, 2017; Asensio, 2003). En 1740 fundaron Purísima Concepción de María, una 
reducción entre los indios pampas al sur del río Salado (Barcelos, 2013, p. 77). Posteriormente, establecieron dos nuevas reducciones, Nuestra Señora del Pilar del Volcán (1746) (Barcelos, 2013, p. 340) y Nuestra Señora de los Desamparados (1749) (Barcelos, 2013, p. 341), ambas ubicadas cerca de la actual Sierra de los Padres. Estas misiones pretendían pacificar a las poblaciones indígenas y reducir las correrías violentas que las enfrentaban con la sociedad colonial. Por esto recibieron un apoyo logístico -ciertamente tímido- de las autoridades de Buenos Aires, quienes además se veían urgidas a ocupar los extensos territorios sureños, presa fácil de potencias imperiales rivales como Francia, Holanda e Inglaterra.

Con esta base geográfica, los jesuitas pudieron llevar adelante expediciones hacia la Patagonia, dos de las cuales resultaron más importantes. La primera se realizó en 1745-1746 y consistió en un viaje en barco a lo largo de la costa atlántica, desde Buenos Aires hasta la desembocadura del río Gallegos (actual provincia argentina de Santa Cruz) (Altic, 2017). Los jesuitas que participaron en este viaje fueron José Quiroga (1707-1784), enviado desde España expresamente para esta tarea por sus conocimientos técnicos, Matías Strobl (1696-1769) y José Cardiel (1704-1782). La segunda expedición, de 1748, consistió en una exploración por tierra realizada por Cardiel y dos intérpretes "serranos", cuyo objetivo era alcanzar el Estrecho de Magallanes. Esta expedición recorrió la actual provincia de Buenos Aires desde la Sierra de los Padres pero, lejos de alcanzar su objetivo, no logró cruzar el río Colorado (Barcelos, 2013: 79-82).

En el Diario del viaje y misión al río del Sauce de Cardiel, referente a la travesía de 1748, no se menciona la Ciudad de los Césares (Cardiel, 1933 [1748]). Pero, a partir de los apuntes realizados por Quiroga y Cardiel durante el viaje anterior de 1745-1746, Pedro Lozano (1697-1752), historiador oficial de la provincia del Paraguay (Cargnel, 2009), redactó la principal fuente de esta experiencia, un "Diario de un viaje a la costa de la mar magallánica" 4 en el que se alude brevemente a los Césares. Allí Lozano indica que, a la altura de la bahía de San Julián (actualmente provincia de Santa Cruz, Argentina), una comitiva dirigida por Cardiel se internó tierra adentro durante varios días. En este viaje, Cardiel padeció "muchos dolores en las junturas de las piernas" y, aunque pudo continuar gracias a colocarse curativos "paños empapados en orina", esto dificultó en gran medida su viaje (Charlevoix \& Muriel, 1916 [1757], p. 432). A pesar de esto, Lozano señala que, de haber tenido autorización, el enfermo Cardiel "se hubiera venido por tierra, descubriendo lo que hay acerca de los decantados, o encantados Césares" (Charlevoix \& Muriel, 1916 [1757], p. 433). El misionero no pudo efectuar tal exploración, y en la expedición terrestre

\footnotetext{
${ }^{4}$ Se publicó como parte del apéndice documental de la Histoire de France de Pierre François Xavier de Charlevoix.
} 
desde la bahía la comitiva solo encontró algunas fuentes de agua y matorrales, sin hallar ni población (indígena ni de ningún tipo) ni tierra fértil.

La producción textual respecto de la Ciudad de los Césares es amplia. Uno de los textos más extensos y significativos es una carta que José Cardiel escribió a José de Andonaegui (1685-1761), gobernador de Buenos Aires, en agosto de 1746 (véase Imagen 3). El jesuita Cardiel tenía amplia experiencia en misiones no completamente consolidadas y en la realización de mapas. En este texto, insiste con firmeza en la existencia de la ciudad; sus principales estrategias argumentales son dos. Por un lado, enuncia la noción de una geografía incompleta del mundo conocido y la posibilidad de que todavía -a mediados del siglo XVIII- se produjesen "descubrimientos". Esta concepción era seguramente compartida por su destinatario. ${ }^{5}$ Así, el jesuita señala:

“El que no se aya descubierto [la Ciudad de los Césares] en tanto tiempo, no me haze fuerza; pues las Batuecas, en medio de España tan poblada por todas partes, estubo tantos centenares de años, o sin descubrirse, o con muy poca o dudosa noticia de que hubiese tal gente. $\mathrm{Y}$ pocos años ha, en medio del Reyno de Mexico, mucho mas poblado de christianos que estas partes, se descubrió una nacion harto política, de quien habria varias dudas se [sic] la habria o no; y mas arriva de la Nueva Vizcaya y del Nuevo Mexico, en donde los mapas antiguos ponen la gran Ciudad de Quiriza, de quien se decian tantas o mas ponderaciones que las que se dicen de los Cesares; y a cuya empresa o conquista fueron tropas de españoles, y se volvian cansados de las dificultades, diciendo que estaba encantada; vulgaridad que dicen luego para palitar [sic] su falta de empeño y constancia, se descubrió la nacion de los pitos, gente de ser que vive en ciudades con edificios altos de suelos, y este es el encanto. Con que habiendo aqui más dificultades que en lo dicho, no debe hacer fuerza el que hasta ahora no se aya descubierto. Ni tampoco me haze fuerza lo que dicen algunos, que si hubiera tales Cesares o poblaciones, era imposible que alguno de ellos no hubiera venido acá: porque se [sic] ninguno de estas partes ha penetrado más que 200 leguas de aquí, solo hasta el Rio del Sause, por las dificultades que se han ofrecido,

\footnotetext{
${ }^{5}$ Ciertamente el "mapa" de los europeos-occidentales solo comenzaría a completarse tras su llegada a Australia (1770) y a la largamente sospechada Antártida (cuyo primer avistamiento fehaciente data aproximadamente de 1820 , sin que se produjeran desembarcos hasta fin de siglo).
} 
que mucho que ellos, teniendo menos medios, y quizas sin caballos, no ayan podido penetrar hasta acá" ${ }^{6}$

Por otro lado, Cardiel acumula informaciones, testimonios y fuentes bibliográficas, que funcionan como notas eruditas en favor de su creencia y producen un efecto de realidad. Cita el "Suplemento a la Historia de España por Mariana", la "Historia de Chile por el padre Ovalle" y "los mapas modernos". El suplemento es la Continuación de la Historia de España escrita por el mercedario José Manuel Miñana (1671-1730), que abarca el período 15261700. Este libro se encontraba en la biblioteca jesuítica de Asunción (Gorzalczany \& Olmos Gaona, 2006: 202-203) y probablemente en otras. Por mapas modernos Cardiel quizás se refiriese a los atlas realizados por cartógrafos holandeses como Jan Janssonius (1588-1664) y Joan Blaeu (15961673), muy abundantes en las bibliotecas jesuíticas (Fraschini, 2005, p. 172; Gorzalczany \& Olmos Gaona, 2006, p. 176). Pero en sentido estricto estos textos, con la excepción de Ovalle, no mencionaban la Ciudad de los Césares, sino simplemente la realización de expediciones hacia el Estrecho de Magallanes. Además, Cardiel presenta como fuentes la biografía de Mascardi que circuló manuscrita,7 una relación "que anda por Buenos Ayres" -tal vez el "Derrotero de un viaje desde Buenos Aires a los Césares" (1707) de Silvestre Antonio de Rojas-, la relación oral de un "corregidor del Perú llamado Quiros o Quiroga", "lo que cuenta un [sic] cautiba" e, incluso, lo que "los indios estan continuamente diciendo". El jesuita reconocía que los relatos podían ser parcialmente falsos, pero ante tanta insistencia juzgaba que "no puede menos de haber algo de lo que se dice, que por algo se dixo, que no ay mentira que no sea hija dalgo" ${ }^{\prime \prime}$ y aprovechaba su posición de intermediación oral con la población indígena patagónica para fundamentar la creencia.

\footnotetext{
6 "Carta del Padre Jesuita Joseph Cardiel escripta al Señor Governador y Capitan General de Buenos Ayres". Biblioteca Nacional de Rio de Janeiro [BNRJ], Coleção Pedro de Angelis, Ms. 508, doc. 1098, ff. 4v-5r. Disponible digital: http://objdigital.bn.br/objdigital2/acervo digital/div manuscritos/mssp0002105/mssp0002105.p df (consultado 15/09/19). En este fragmento, Cardiel recurre a lugares comunes de las geografías imaginarias de los siglos XVI, XVII y XVIII. Las Batuecas corresponde a la leyenda de que en la Sierra de Francia (actualmente provincia de Salamanca, comunidad autónoma de Castilla y León, España) habría existido durante varios siglos un pueblo descendiente de los visigodos en completo aislamiento. Una comedia de Lope de Vega fue relevante en la popularización de esta leyenda (Saracino, 2016).

7 Probablemente se trate de la "Vida apostólica y glorioso martirio del venerable P. Nicolás Mascardi de la Compañía de Jesús" escrita por Diego Rosales (1601-1677) (véase Urbina C., 2020, p. 6).

8 "Carta del Padre Jesuita Joseph Cardiel escripta al Señor Governador y Capitan General de Buenos Ayres". BNRJ, Coleção Pedro de Angelis, Ms. 508, doc. 1098, f. 7r (subrayado original).
} 


\section{Imagen 3}

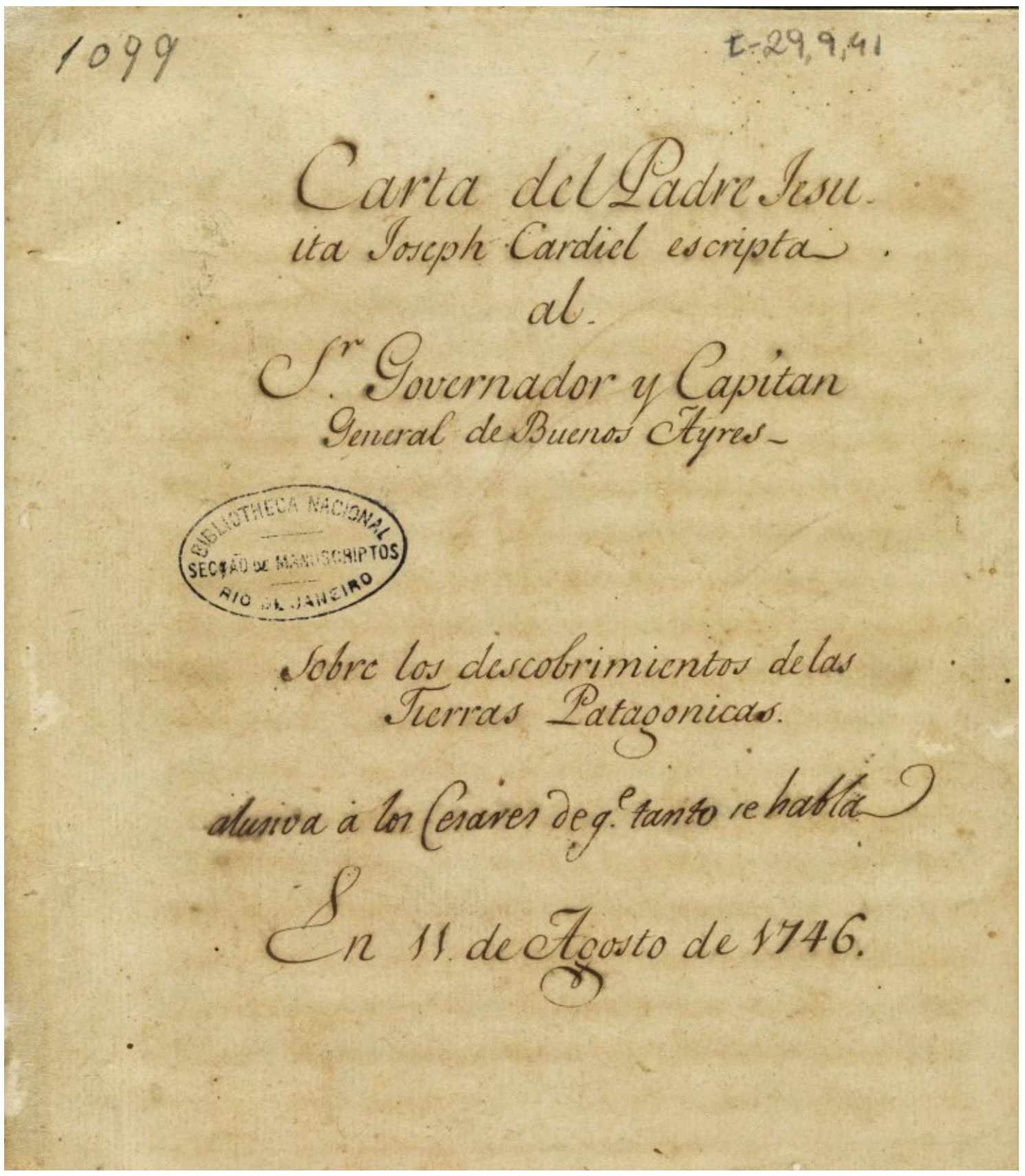

“Carta del Padre Jesuita Joseph Cardiel escripta al Señor Governador y Capitan General de Buenos Ayres" sobre la Ciudad de los Césares (1746), conservada en y digitalizada por la Biblioteca Nacional de Rio de Janeiro.

Pero esto no necesariamente significa que los jesuitas del Paraguay creyesen plenamente en la Ciudad de los Césares. Otros textos contemporáneos exhiben un mayor escepticismo. A manera de ejemplo, Pedro Lozano, el historiador de la provincia del Paraguay, escribió extensamente sobre la Ciudad de los Césares en una carta a Juan de Alzola (1670-1743), un jesuita que se había desempeñado como procurador en España. La fuente principal de este escrito 
es "un papel que avra seis años me dio el padre Rillo"9 -probablemente Lorenzo Rillo (1676-1729), provincial desde 1727 hasta su muerte-, el cual "parece sea de letra del celebre padre Lezana", tal vez en referencia al jesuita nacido en Santiago del Estero Diego de Lezana (1660-1729). Lozano también da cuenta de su conocimiento de otros relatos, entre ellos el de Mascardi. En cualquier caso, la acumulación de testimonios no convence plenamente al historiador y solo sirve para otorgar a la Ciudad de los Césares una "apariencia de verdad": "Con todo esso yo no lo creo [el hecho de la existencia de la ciudad], y solo embie dicho papel, como antes dije a Vuestra Reverencia, para que se entretuviesse en el viage, y para esso qualquiera patraña sirve; pero esta no dexa de tener su apariencia de verdad". ${ }^{10}$

Otros ejemplos de escepticismo, tal vez más significativos, provienen del propio Cardiel. Aparentemente, este habría escrito una carta a principios de 1746 (quizás dirigida al mismo gobernador de Buenos Aires) en la que hablaba al mismo tiempo de "exageraciones y fabulas" y de la posibilidad de encontrar "algo". ${ }^{11}$ A su vez, este misionero volvió a referirse a la Ciudad de los Césares al final de una carta relatoria firmada en diciembre de 1747. El objetivo de este documento era difundir la labor de los misioneros del Paraguay en otras provincias jesuíticas, y tuvo una circulación no despreciable al interior de la orden, pues el mismo Cardiel afirma que estaba siendo copiado por otros

\footnotetext{
9 "Capitulo de una carta del P. Pedro Lozano al P. Juan de Aloza sobre los Cesares que dizen estan poblados en el Estrecho de Magallanes". Archivo General de la Nación [AGN], Sala VII, Colección Biblioteca Nacional, 364, doc. 6383, ff. 1r-v.

10 "Capitulo de una carta del P. Pedro Lozano al P. Juan de Aloza sobre los Cesares que dizen estan poblados en el Estrecho de Magallanes". AGN, Sala VII, Colección Biblioteca Nacional, 364, doc. 6383, f. 2 v (subrayado nuestro).

${ }^{11}$ Decimos "aparentemente" porque, en un texto temprano, Guillermo Furlong cita esta carta sin dar referencias a su ubicación archivística. La carta sería "del 11 de abril de 1746" y estaría "dirigida al gobernador Cevallos", lo cual es imposible en la medida en que Cevallos solo arribaría a América en la década de 1750. El fragmento citado por Furlong, alusivo a la Ciudad de los Césares, es el siguiente: “De Buenos al Estrecho... son 200 leguas. Ahí se dice que está la famosa ciudad de los Césares, de quien cuentan tanto como de la encantada Paititi, y de la otra de Quiyisa... Ahora tengo orden de ponerme 100 leguas de Buenos Aires para formar allí un pueblo de infieles y desde allí hacer por tierra este famoso descubrimiento, para ver qué fundamento tengan tantas exageraciones y fabulas que por tales tengo lo más, aunque no dejará de haber algo" (Cardiel, 1933, p. 32). Esta misma cita fue reproducida en un libro de Furlong cinco años posterior, también sin referencia archivística (Furlong, 1938, p. 144). En 1953, Furlong publicó un listado de todos los textos y mapas, editados o inéditos, firmados por Cardiel o atribuidos a él; significativamente, en este listado no figura la mencionada carta (Furlong, 1953: 54-109). La similitud de la fecha de esta presunta misiva (11 de abril de 1746) con la carta efectivamente conocida dirigida a un gobernador de Buenos Aires (11 de agosto de 1746) sugiere la posibilidad de que Furlong haya citado o reformulado una referencia a partir de apuntes personales y no del documento concreto. El texto citado es indudablemente compatible con otros escritos de Cardiel. El escepticismo está más enfatizado que en la carta a José de Andonaegui, pero la dificultad de precisar el destinatario del texto inhabilita una interpretación definitiva.
} 
jesuitas mientras lo escribía (Furlong, 1953, p. 211). Formalmente estaba destinado a un amigo y maestro del autor, el predicador español Pedro de Calatayud (1689-1773), y es probable que no hubiera circulado por fuera de los canales de la Compañía. Aquí el escepticismo se sitúa en la estela inaugurada por Lozano y está incluso más enfatizado:

“En cuanto a lo $3^{\circ}$ sobre la ciudad de los Césares, tan decantada, que dicen formaron Europeos perdidos en esas costas y en el Estrecho, y que está escondida en esa dilatada tierra de Magallanes, he hecho exquisitas diligencias en dos años por mar y por tierra de indios cercanos y forasteros de lejanas tierras. [...] Cuanto más averiguo, hallo más fundamentos para creer que no hay nada. Que a lo más dió fundamento a estos embustes el haber hecho algunas cabañas algunos pocos que se salvaron en la pérdida de algunos navíos, que con el tiempo, o se han acabado, o su descendencia vive como los demás indios. Ahora dentro de pocas semanas voy por mar y por tierra al Río del Sauce y más allá, y averiguaré con el favor de Dios este punto" (Furlong, 1953, p. 213).

En vistas de que la creencia en geografías imaginarias solía ser plasmada en los mapas (Barcelos, 2013: 19-20), la producción cartográfica de Cardiel también podría servir para evaluar la creencia de los jesuitas en la Ciudad de los Césares. Carmen Martínez Martín ha atribuido a este misionero dos mapas sobre la "Tierra Magallánica" conservados en Madrid (Martínez Martín, 1994: 159-160): “Tierra de Magallanes, con las Naciones que se han podido descubrir en viages de Mar y tierra desde el año de 1745 hasta el de 1748" y "Mapa de Magallanes de 1751" (Imagen 4). ${ }^{12}$ Mirela Altic le atribuye también un mapa sin título preciso conservado en Buenos Aires (Altic, 2017: 164-165). Todos tienen la peculiaridad de informar, con mayor o menor detalle, sobre las clasificaciones étnicas de la población indígena -punto sobre el que volveremos-. Pero en ninguno de ellos se menciona ni se localiza la Ciudad de los Césares.

\footnotetext{
12 “Tierra de Magallanes, con las Naciones que se han podido descubrir en viages de Mar y tierra desde el año de 1745 hasta el de 1748". Biblioteca Nacional de España [BNE], Sala Goya, Cartografía, Sede de Recoletos, MR/42/362/1; “Mapa de Magallanes de 1751". Madrid, BNE, Sala Goya, Cartografía, Sede de Recoletos, MR/42/403; Mapa de la Patagonia atribuido a Cardiel sin título preciso. AGN, Mapoteca, II, 158.
} 


\section{Imagen 4}

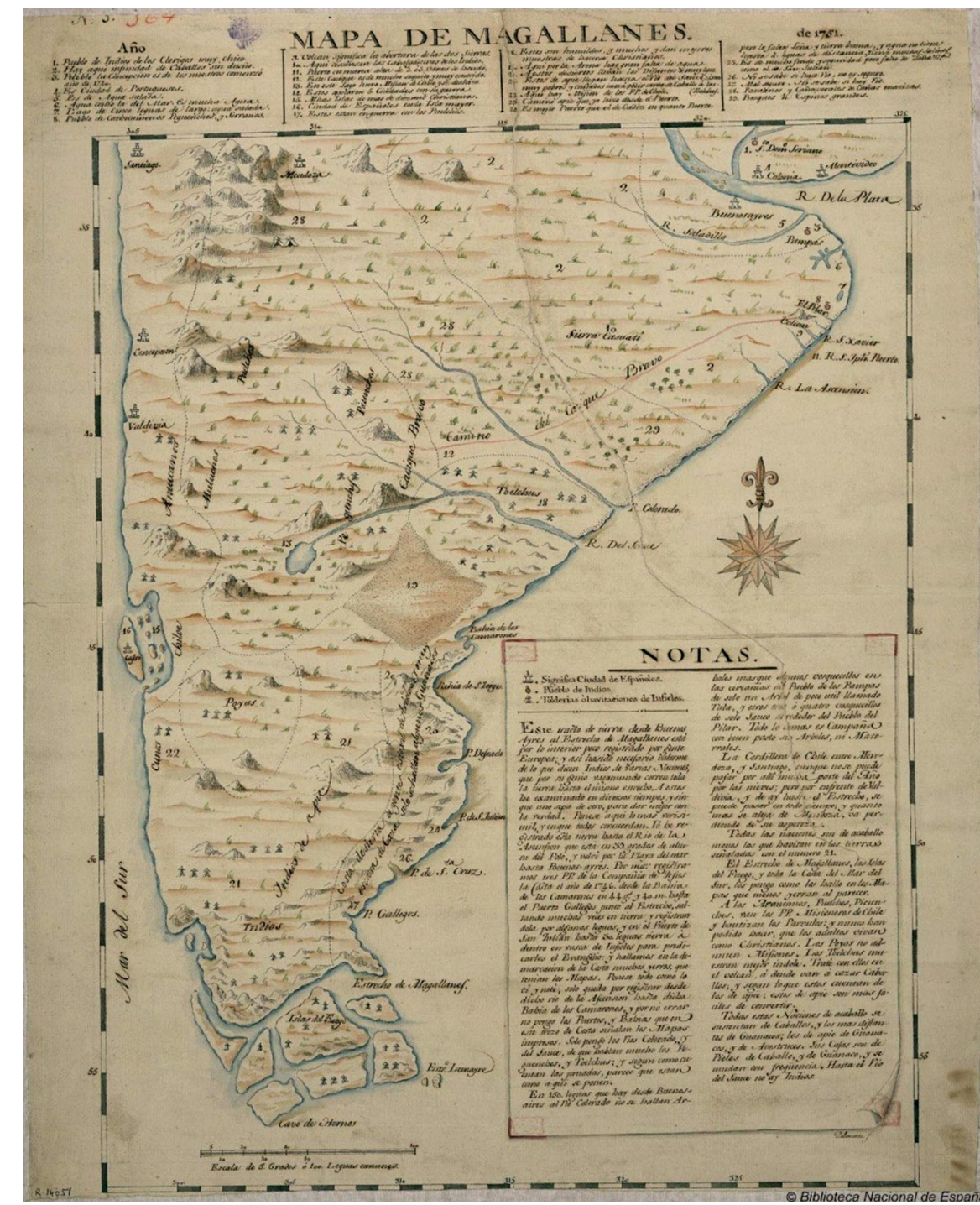

“Mapa de Magallanes de 1751", atribuido a José Cardiel y conservado en la Biblioteca Nacional de España.

¿Cómo interpretar entonces la existencia de un solo documento extraño, ingenuo, que contradice la tendencia escéptica? Nos referimos, desde luego, a la carta de Cardiel a José de Andonaegui en agosto de 1746, anteriormente citada. Es probable que la respuesta a este interrogante deba buscarse en la coyuntura concreta de producción y recepción de este escrito. Es claro que Cardiel no pudo modificar su opinión sobre la Ciudad de los Césares de un año a otro, tiempo en el cual no se produjo ninguna nueva expedición hacia el sur. Por eso pensamos que la carta de agosto de 1746 manifiesta la posibilidad de utilizar la tradicional descripción maravillosa de la Ciudad de los Césares como parte de una estrategia jesuítica de manipulación, en un momento muy específico del proyecto de evangelización meridional. La mayor parte de las cartas y textos de los jesuitas del Paraguay sobre la Ciudad de los Césares estaban desprovistos 
de peticiones y demandas concretas. Ilustran una práctica de averiguación geográfica que estuvo extendida en la Compañía de Jesús del siglo XVIII. Incluso la mayoría de los textos tendieron a circular únicamente al interior de la orden. En estos casos parece predominar el escepticismo y la incredulidad, ciertamente en grados variables. En cambio, el único documento genuinamente "crédulo" está dirigido a una autoridad política y contiene una petición concreta de recursos. En este sentido, la carta de agosto de 1746 puede ser considerada una performance argumental.

Tal vez no sea exagerado asociar la escritura de Cardiel a la "calculada estrategia retórica" que Stephen Greenblatt identificó en las cartas de Cristóbal Colón sobre América (Greenblatt, 1991: 72-74 especialmente). Según el académico norteamericano, las constantes referencias de Colón -y otros cronistas- a las maravillas de las islas del Caribe no constituyen un discurso "perfectamente transparente", sino que deben ser inscriptas en una "performance y producción de asombro" motivada por razones políticas, económicas y geográficas, puntualmente la inexistencia de grandes cantidades de oro en la región. Cardiel también recurrió al discurso de lo maravilloso al mencionar "algunas minas de oro y plata", "un cerro de diamantes, y otro en otro parage de oro" y la posibilidad de "allar de presiosidades a trueque de quentas de vidrio y otros abalorios". ${ }^{13}$ Asimismo, Cardiel incluyó en su carta argumentos que no figuran en otras producciones jesuíticas pero que tocaban vetas sensibles de las autoridades, como la posibilidad de que existiesen holandeses $u$ ingleses en la Patagonia, confundidos con "Césares" blancos. ${ }^{14}$ La dimensión pragmática tanto de la descripción maravillosa como de las prevenciones geopolíticas es evidente y Cardiel explicita sus intenciones al final de la misiva: “O quanto me alegrara yo que Vuestra Señoria, sin hacer caso de algunos que quieren passar por chriticos y discretos haciendose incredulos a todo, pusiese todo empeño en aberiguar ese punto, conseguiendo con su eficacia lo que otros no han podido? [sic]". ${ }^{15}$ Para lo cual se requería, según Cardiel, de lo siguiente: “300 paysanos [...] llevando cada uno 5 o 6 caballos, y

13 "Carta del Padre Jesuita Joseph Cardiel escripta al Señor Governador y Capitan General de Buenos Ayres". BNRJ, Coleção Pedro de Angelis, Ms. 508, doc. 1098, ff. 3v, 6r y 8v respectivamente.

${ }^{14}$ Según Cardiel, la "cautiba" relató que "llevandola a muy distantes tierras acia el sudoeste, encontró unas casas, y en ellas gente blanca y roxa; y que estando ella muy alegre, jusgando ser gente española, se le aguó todo el contento, viendo que no les entendia palabra". Más adelante Cardiel escribió que este "no entenderseles la lengua es muy factible; siendo aquella poblacion [...] de la cauptiba de gente olandesa, o inglesa". "Carta del Padre Jesuita Joseph Cardiel escripta al Señor Governador y Capitan General de Buenos Ayres". BNRJ, Coleção Pedro de Angelis, Ms. 508, doc. 1098, ff. 6v-7r.

15 "Carta del Padre Jesuita Joseph Cardiel escripta al Señor Governador y Capitan General de Buenos Ayres". BNRJ, Coleção Pedro de Angelis, Ms. 508, doc. 1098, f. 7v. 
[...] polvora y valas a 6 a 7 libras de cada cosa [...] hachas, varretas, azadas [...] llevarían tambien de sus casas, y cueros [...] [y] 5 rezes para cada uno". ${ }^{16}$

En concreto, pues, el "empeño en averiguar ese punto", asociado a cerros de diamantes y minas de oro y plata, se materializaba en una pragmática petición de financiamiento, que ilumina el sentido de la creencia ingenua en la ciudad maravillosa. De este modo, la carta puede inscribirse en el plano más amplio de las escrituras jesuíticas propagandísticas relativas a sus proyectos misionales y concentradas en obtener apoyo para los mismos: es, así, la confección de un "lenguaje para el otro" relativo a la Ciudad de los Césares (Certeau, 2007, pp. 177-179): una fachada retóricamente construida (Certeau, 2007, pp. 185-188) que intentaba transmitir una disposición específica al receptor y que se distinguía sensiblemente de un "lenguaje interior" jesuítico, con más limitados canales de circulación.

\section{De césares cristianos a indígenas cristianizables}

Según la carta de José Cardiel a las autoridades, se requerían 300 personas, 1500 vacas y entre 1500 y 1800 caballos para hallar la Ciudad de los Césares. Ciertamente no debería descartarse la voluntad del jesuita por resolver el enigma de la ciudad. Pero de acuerdo a los apuntes de Lozano sobre el viaje marítimo de 1745-1746, anteriormente citados, este misionero había considerado posible solucionar la incógnita de los Césares desde la bahía de San Julián, con una pequeña comitiva y estando él mismo enfermo de las piernas (Charlevoix \& Muriel, 1916 [1757], p. 433). Dada la cantidad de los recursos solicitados en agosto de 1746, es probable que el objetivo de los jesuitas fuera más amplio: la exploración cabal de la Patagonia, el establecimiento de algunos poblados permanentes $\mathrm{y}$, en última instancia, la "conquista espiritual" de la “Tierra Magallánica”. La evangelización de los jesuitas chilenos entre los poyas del Nahuel Huapi había fracasado definitivamente en 1717. La estrategia de los jesuitas del Paraguay consistía en comenzar la evangelización por los pampas y serranos -de acuerdo a sus categorías etnográficas- y avanzar finalmente hacia los tehuelches y patagones. En el momento en que Cardiel escribió esta carta, se acababa de fundar la segunda reducción en la actual provincia de Buenos Aires $\mathrm{y}$, por tanto, este proyecto estaba en auge. Sin duda exageradamente, el misionero señalaba en 1747 que la "mission austral, o del sur" era "la mas principal" de la provincia. ${ }^{17}$ Pero si bien existió apoyo político de las autoridades, el abultado financiamiento solicitado jamás se concretó.

\footnotetext{
16 "Carta del Padre Jesuita Joseph Cardiel escripta al Señor Governador y Capitan General de Buenos Ayres". BNRJ, Coleção Pedro de Angelis, Ms. 508, doc. 1098, f. 8r-v.

17 "Difficulcultades, que suele haber en la conversión de los infieles y medios para vencerlas". AGN, Sala VII, Colección Biblioteca Nacional, 289, 4390/1, f. 8r.
} 
Ahora bien, aunque la insistencia "ingenua" de Cardiel puede obedecer a una performance argumental, resta considerar el hecho de que otros jesuitas también escribieron sobre la Ciudad de los Césares, lo que permite pensar en la existencia de todo un corpus sobre esta ciudad en la provincia del Paraguay. A fines de la década de 1730, la máxima autoridad de la Compañía de Jesús, Francisco Retz (1673-1750) conminó al provincial Antonio Machoni (1672-1753) a comunicarle la información que había podido adquirir sobre los Césares (Martínez Martín, 1994: 166-167). Machoni respondió con una breve carta en que menciona esta problemática. Además de Lozano y Cardiel, Matías Strobl, uno de los responsables de las reducciones entre pampas y serranos, también se refirió a la ciudad en una carta que no hemos podido hallar (Guevara, 1882 [c. 1760], p. 287). Lozano volvió a mencionar en más de una ocasión la Ciudad de los Césares en su Historia de la Compañía de Jesús en el Paraguay (1754-1755), impresa en dos volúmenes en Madrid. También se atribuyó (seguramente de manera errónea) un texto titulado “Derrotero desde la ciudad de Buenos Aires hasta la de los Césares, que por otro nombre llaman la Ciudad Encantada" al jesuita Thomas Falkner (1707-1784). ${ }^{18}$ Pareciera entonces que a lo largo de toda la jerarquía burocrática de la provincia jesuítica del Paraguay existía producción textual y argumental en torno a la Ciudad de los Césares, independientemente de la intención o no de manipular a las autoridades políticas.

Un aspecto clave en este sentido es el equívoco propio de la expresión "Césares". Como se ha señalado desde las primeras investigaciones, en los siglos XVII y XVIII la palabra se utilizaba indistintamente para aludir a la población blanca de la ciudad y a la población indígena circundante (Gandía, 1933). Sanchez ha indicado incluso que existió "una tentativa de asimilación entre estos dos tipos de Césares" (Sanchez, 1996). Los vínculos referidos entre estos dos grupos variaban según las versiones; en algunos casos los indígenas se presentaban subordinados a los blancos, mientras que en otros eran los agentes que impedían la salida de estos de la ciudad o la llegada de los viajeros a sus inmediaciones. Pero la cuestión más relevante es que los dos grupos solían aparecer confundidos y mezclados en cuanto a la enumeración de sus características.

Esta confusión parece sensiblemente acentuada en los textos de los jesuitas del siglo XVIII. Es posible que los misioneros hayan pensado que detrás

\footnotetext{
18 "Derrotero para ir a la Ciudad que llaman de los Cesares hecho por un Ingles Jesuita el Padre Tomas Falconer de la Compañia de Jesus". BNRJ, Coleção Pedro de Angelis, Ms. I-29,9,58. Disponible digital: http://objdigital.bn.br/objdigital2/acervo digital/div manuscritos/mssp0002241/mssp0002241.p df (consultado 10/09/19). La atribución es seguramente errónea porque el autor señala que "todo lo que aquí va referido (...) yo mismo lo he andado, lo he visto y tocado por mis manos" mientras que como veremos en 1774 Falkner descreería de la ciudad-, además de que se refiere a España como "nuestra España", siendo Falkner inglés de nacimiento.
} 
de la creencia en los Césares se encontraba un grupo indígena susceptible de ser evangelizado exitosamente. Al fin y al cabo, era una idea extendida que los indígenas de la Patagonia eran más blancos que otros amerindios, y esta opinión había sido expresada por el primer provincial del Paraguay, Diego de Torres Bollo (1550-1638) (Gandía, 1933, p. 10). Pero es más probable que la imaginación y los conocimientos de los jesuitas con respecto a la población indígena de la porción más meridional de la Patagonia se hayan basado en los rumores en torno a la Ciudad de los Césares.

El razonamiento de los misioneros con respecto a la factibilidad de la conversión de cada grupo indígena dependía de un esquema de clasificaciones étnicas cuyo origen puede rastrearse hasta José de Acosta (1540-1600). En efecto, los jesuitas cumplieron un rol privilegiado en la producción de conocimientos sobre las sociedades indígenas americanas. Las clasificaciones que elaboraron tuvieron un efecto performativo clave en las prácticas concretas de evangelización. Acosta en particular elaboró una clasificación evolutiva de las sociedades americanas y asiáticas, desde las nómades y errantes hasta las más "civilizadas" y letradas, que definía estrategias específicas de conversión (Maldavsky, 2012: 29-69; Romano, 2011; Wilde, 2018). A mediados del siglo XVIII, Cardiel reactualizó estos esquemas en un texto en el que dividió a la población indígena entre "indios de a caballo" e "indios de a pie". Los primeros se caracterizarían por su "falta de racionalidad y policia", su "inata inercia", su "orrible orror" al trabajo, sus prácticas de caza y recolección y su violencia, mientras que los segundos serían "labradores, o chacareros" que "viven en casas y pueblos con obediencia a sus caciques". ${ }^{19}$

El aspecto extraño es que este texto, y muchos otros que escribieron los jesuitas del Paraguay sobre la evangelización de la Patagonia o la Ciudad de los Césares, mencionan insistentemente que en el extremo meridional de la Cordillera de los Andes y en el Estrecho de Magallanes habría "indios de a pie", a veces definidos como agricultores. Así, aunque se reconoce que de "los genios

19 "Difficulcultades, que suele haber en la conversión de los infieles y medios para vencerlas". AGN, Sala VII, Colección Biblioteca Nacional, 289, 4390/1, f. 2v. Este texto fue publicado por Milcíades Alejo Vignati en 1956 (Cardiel, 1956 [1747]). En el Archivo General de la Nación de Buenos Aires se encuentran dos manuscritos distintos de este documento. El transcripto por Vignati y el citado aquí es el primero. Los dos documentos poseen algunas leves variantes entre sí. Véase AGN, Sala VII, Colección Biblioteca Nacional, 289, 4390/2. Cardiel escribió otro documento similar, del cual se conserva una copia tardía en Roma, que debería ser considerado en un análisis sobre la circulación de clasificaciones indígenas y prácticas de misión a mediados del siglo XVIII. Véase "Medios para reducir a vida racional y christiana a los indios infieles que viven vagabundos sin pueblos ni sementeras", Archivum Romanum Societatis Iesu (Roma), Paraq. 24, ff. 1r-8r. 
de los [indígenas] de mas adentro poco sabemos" ${ }^{\prime \prime 20}$ tampoco se duda en señalar que:

\begin{abstract}
"Acerca de estas tierras [la Patagonia] ay mas especiales motibos que acerca de otras, para procurar su conquista assi espiritual como temporal, por que ademas de haver tierra adentro naciones de indios labradores, segun se tiene noticia de los de a caballo comarcanos, y tambien de a pie, las quales dos propriedades de ser labradores y de a pie son, segun nos muestra la experiencia, grande desposicion para recibir el Evangelio, que los de a caballo y vagabundos sin sementeras es casi imposible el convertirlos". ${ }^{21}$
\end{abstract}

Las representaciones cartográficas del misionero también asignaban una amplia porción del territorio meridional de la cordillera de los Andes, cercano al Estrecho de Magallanes, a estos "indios de a pie” (véanse Imágenes 4 y 5). Curiosamente, este jesuita deslizaba que "quizás" los "césares" españoles tampoco poseyeran caballos. Además, la voluntad de conversión se aplica a estos "césares blancos" en un sentido similar al de sus vecinos indígenas, puesto que en el mejor de los casos tendrían "muchos errores en la Fe y las costumbres" por haber estado "sin sacerdotes tantos años". ${ }^{22}$ El propio Nicolás Mascardi creía que no solo los Césares blancos eran medianamente cristianos, sino que también lo habían sido sus vecinos indígenas, evangelizados en las míticas campañas del apóstol Tomás (Furlong, 1963: 51-52 y 122-123; Grafton et al., 1995: 142-143). Un último componente que los jesuitas asignaban a la población indígena de este territorio -fundamental para su buena conversiónera el poseer "sementeras". Es probable que, en realidad, este fuera un rasgo característico de la Ciudad de los Césares, descripta en los relatos como un paraíso agrícola “de matriz edénica” (Tieffemberg, 2015, p. 22).

\footnotetext{
20 "Difficulcultades, que suele haber en la conversión de los infieles y medios para vencerlas". AGN, Sala VII, Colección Biblioteca Nacional, 289, 4390/1, f. 8v.

21 "Carta del Padre Jesuita Joseph Cardiel escripta al Señor Governador y Capitan General de Buenos Ayres". BNRJ, Coleção Pedro de Angelis, Ms. 508, doc. 1098, f. 3v (subrayado nuestro). 22 "Carta del Padre Jesuita Joseph Cardiel escripta al Señor Governador y Capitan General de Buenos Ayres". BNRJ, Coleção Pedro de Angelis, Ms. 508, doc. 1098, f. 7v.
} 


\section{Imagen 5}

Tierra de Magallanes; conlas (aciones que re Jun podido descuin, en

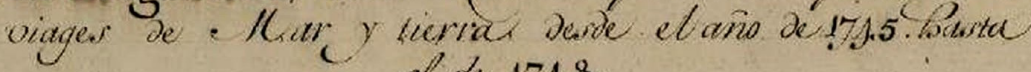

$$
\text { el de } 17.8 .8 \text {. }
$$

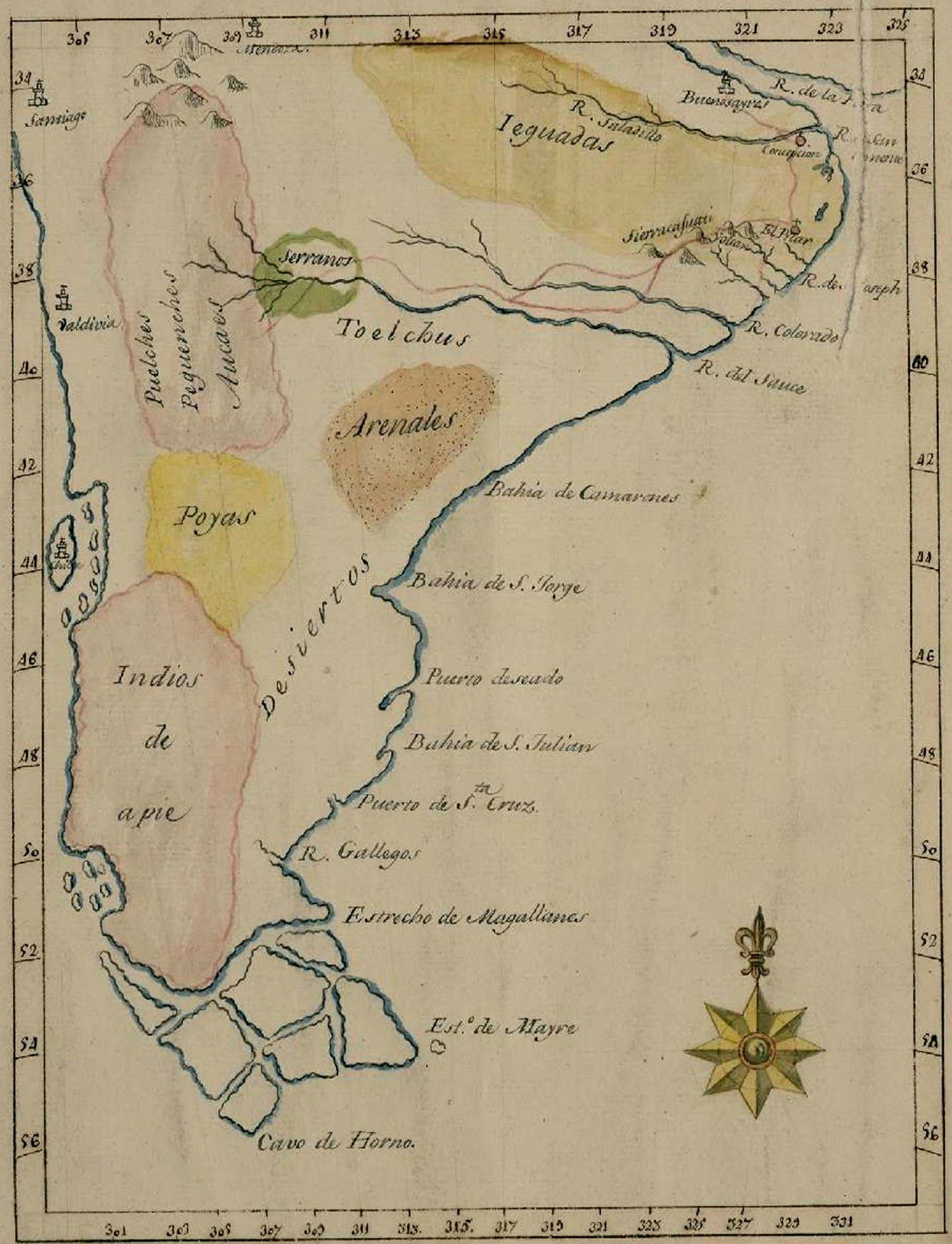

Mapa "Tierra de Magallanes, con las Naciones que se han podido descubrir en viages de Mar y tierra desde el año de 1745 hasta el de 1748", atribuido a José Cardiel y conservado en la Biblioteca Nacional de España. 
Desde luego, ni los viajes de los jesuitas ni la investigación arqueológica profesional encontraron rastros de estos indígenas agricultores en la porción más austral de Sudamérica. La creencia en ellos es un componente más de las geografías imaginarias sudamericanas. En este sentido, si la búsqueda jesuítica de la Ciudad de los Césares podría pensarse como la prolongación de la persecución medieval del perdido reino cristiano del Preste Juan o del Santo Grial (Ainsa, 1992: 44-47), las afirmaciones dieciochescas acerca de indígenas agricultores y sedentarios fácilmente convertibles -precisamente en el extremo más ignorado de la geografía sudamericana- podrían considerarse una suerte de transmutación desmitificada de esta búsqueda de "lo perdido" cristiano.

\section{La deriva ilustrada}

José Guevara (1719-1806), el último historiador oficial de la provincia jesuítica del Paraguay antes de la expulsión, se refirió extensamente a la Ciudad de los Césares a partir de un escepticismo sólido. En una historia escrita hacia 1760, llamó a la ciudad "fábula" y "cuento ordinario del vulgo" (Guevara, 1882 [c. 1760], p. 247) y a sus fuentes, "fingidas novedades" (Guevara, 1882 [c. 1760], p. 247) incapaces de resistir "una exacta crítica" (Guevara, 1882 [c. 1760], p. 282). Es probablemente la primera referencia ilustrada de los jesuitas del Paraguay a esta cuestión. Ya después de la expulsión, el jesuita José Sánchez Labrador (1717-1798) escribió en su manuscrito Paraguay católico (c. 1770) que "no fuera de estrañar" que por fin "se desterrase al país de las fábulas" la existencia de la Ciudad de los Césares (Furlong, 1992, p. 62). Entre otras cosas, este jesuita juzgaba que "[h]ace fuerza para no creer la existencia de dicha ciudad" que los indígenas nunca hubiesen alcanzado a los Césares, a pesar de recorrer toda la Patagonia. Así, Sánchez Labrador consideraba que la Ciudad de los Césares no era más que una leyenda resultado de los "genios noveleros de los indios australes" (Furlong, 1992, p. 63).

El jesuita de origen británico Thomas Falkner -que había sido comisionado de la Royal Society en el Río de la Plata- fue igualmente escéptico sobre la Ciudad de los Césares. En A Description of Patagonia (1774) recurrió a argumentos racionalistas para negar la creencia en la ciudad. En un sentido muy similar a Sánchez Labrador, el relato al respecto era para él un "cuento" "enteramente falso y sin fundamento", derivado de una "mala inteligencia de las relaciones que dan los indios" (Falkner, 2003 [1774], p. 185). Para Falkner, cuando los indígenas nómades de la Patagonia aludían a ciudades de blancos, se referían o a Buenos Aires o a los poblados de Chile-dependiendo de su interlocutor-. También rechazó la verosimilitud del relato del origen de la Ciudad de los Césares a partir de un naufragio en el Estrecho de Magallanes, porque la población no habría podido sobrevivir ni mantenerse apartada de sus vecinos indígenas sin mestizarse. 
En ocasiones, estos jesuitas cuestionaron lo que juzgaban desatinos imaginativos de la población indígena. Sin embargo, en general sus ideas son resultado de las transformaciones epistemológicas de la segunda mitad del siglo XVIII que ha descripto en detalle Jorge Cañizares Esguerra. Siguiendo de cerca la argumentación de Lorraine Daston, el historiador ecuatoriano afirma que en las décadas finales del siglo XVIII nació un novedoso "arte de la lectura" a partir del cual los testimonios sobre América se analizaron en función de su coherencia interna (Cañizares Esguerra, 2007: 35-114 especialmente). Se reemplazó, así, la crítica "externa" de los testimonios propia de la lectura humanística -basada en la posición social y las características de los testigospor una crítica "interna" especialmente escéptica. Los jesuitas exiliados en Italia resistieron varios de estos postulados epistemológicos (Cañizares Esguerra, 2007: 358-368 y 405-441), pero en más de una ocasión, como lo muestra el propio Cañizares Esguerra, recurrieron a la crítica interna. La falta de coherencia de los testimonios sobre la Ciudad de los Césares es el argumento central de los jesuitas del Paraguay de la segunda mitad del siglo XVIII para descreer de la misma.

Así pues, en esta época, y sobre todo en el exilio posterior a 1767, las representaciones jesuíticas sobre la Ciudad de los Césares sufrieron un cambio y se orientaron a un escepticismo marcado. Ahora bien, creemos que el contexto histórico y político permanece como una variable relevante a la hora de interpretar este escepticismo. Guevara, Sánchez Labrador y Falkner escribieron después del último viaje de los jesuitas al sur, realizado por Cardiel en 1748 (Barcelos, 2013, p. 81), en el que no hubo rastro ni de la ciudad ni de los "indios de a pie" abiertos a la evangelización. Ese fue el último intento de los jesuitas del Paraguay por adquirir información testimonial sobre la "Tierra Magallánica" y terminó en un fracaso. Además, estos jesuitas escribieron después de la frustración de las reducciones de pampas y serranos, las más australes que habían logrado establecer los misioneros. En 1753, en efecto, se abandonó la última que permanecía en pie, Purísima Concepción de María, como consecuencia de conflictos internos. El abandono de esta reducción tuvo como consecuencia la cancelación del proyecto jesuítico de evangelización de la Patagonia. Si alguna vez lo había tenido -como herramienta de manipulación o de indagación sobre las características étnicas de la población indígena-, la Ciudad de los Césares había perdido su sentido.

\section{Reflexiones finales}

Durante el siglo XVIII, los jesuitas de la provincia del Paraguay llevaron adelante un intento frustrado por evangelizar la actual Patagonia, conocida como “Tierra Magallánica”. En este contexto político y religioso, algunos de los miembros de la orden realizaron expediciones en busca de la Ciudad de los 
Césares y escribieron textos en los que esta geografía imaginaria ocupaba un lugar central. Estas cartas, relaciones y diarios de viaje conforman representaciones discursivas que poseen concretos contextos y coyunturas de producción, circulación y recepción. Desde el punto de vista de la creencia en geografías imaginarias, la escritura jesuítica manifiesta una ambivalencia fundamental, que solo resulta comprensible en función de estas coyunturas. En efecto, la mayoría de las cartas y relaciones que se elaboraron a mediados del siglo XVIII exponen una sospecha débil en la Ciudad de los Césares, un general escepticismo matizado pero confesado sin rodeos. En cambio, una carta específica, que contiene un pedido de financiamiento para la realización de viajes hacia el sur dirigido a las autoridades políticas de la gobernación de Buenos Aires -parte del Virreinato del Perú- trasluce una creencia firme y sólida. Creemos que esta (re)presentación discursiva debe interpretarse como una puesta en escena, una performance calculada en función de las necesidades de la coyuntura y de los receptores. Este contexto específico habilitó el uso de la creencia en la Ciudad de los Césares como estrategia de manipulación de cara a quienes podían financiar un ambicioso proyecto de evangelización de la "Tierra Magallánica". Las descripciones de maravillas y riquezas, los argumentos bibliográficos y eruditos e, incluso, las alusiones geopolíticas a la competencia inter-imperial deben considerarse componentes de esta apuesta pragmática.

No obstante, esto no habilita a considerar que los jesuitas del Paraguay "mintiesen". En la primera mitad del siglo XVIII, parece existir una conveniente creencia débil y flotante, que se afirma en algunas representaciones y se niega y matiza en otras, en el marco de una amplia producción, circulación y acumulación de informaciones por parte de todos los sectores de la jerarquía de la Compañía con respecto a esta ciudad. Este proceso de producción, circulación y acumulación debe entenderse como parte de un esfuerzo más amplio por conocer los territorios australes, de los que la creencia en la ciudad era solo uno de los componentes. En especial, los jesuitas estaban especialmente interesados por obtener los datos etnológicos necesarios para integrar a la población indígena patagónica dentro de los esquemas clasificatorios usados para organizar las tareas misionales. En estos esquemas, se establecía una distinción fundamental entre los indígenas "de a pie" y "de a caballo" en función de sus aptitudes para la evangelización. Es probable que los rumores en torno a la Ciudad de los Césares hayan llevado a los jesuitas del Paraguay a concebir la existencia de una población indígena "a pie", sedentaria y agricultora, susceptible de ser evangelizada. Los ignacianos prolongaron así las geografías imaginarias de lo perdido cristiano en el extremo meridional de Sudamérica, incluso aunque no estuviesen convencidos de la existencia de la ciudad.

Estas nociones de creencia flotante, pragmática puesta en escena y confusión de rasgos entre "césares" blancos y "césares" indígenas son 
privativas de los jesuitas que viajaron y escribieron en la primera mitad del siglo XVIII, mientras el proyecto de evangelización de la Patagonia y las reducciones de pampas y serranos estaban en pie. En la segunda mitad de esta centuria, los jesuitas exhibieron un escepticismo pleno, en diálogo con el pensamiento ilustrado. Ahora bien, a la hora de interpretar la evolución de esta creencia, no debería dejar de tenerse en consideración el fracaso de las reducciones mencionadas, es decir el fin del proyecto jesuítico de evangelización meridional.

Para entender el significado de la Ciudad de los Césares entre los jesuitas del Paraguay en el siglo XVIII, es todavía necesario profundizar en aspectos como la producción cartográfica sobre la Patagonia y las expediciones concretas realizadas desde el Paraguay. Creemos que un abordaje de estas problemáticas desde el punto de vista de la historia cultural, como el efectuado en este trabajo, contribuye a iluminar la problemática de la evangelización "magallánica" con una luz diferente a la tradicional. En este sentido, los interrogantes de fondo que guiaron esta investigación son entender los alcances de las transformaciones intelectuales que tuvieron lugar en el siglo XVIII, indagar en qué medida se verifica una persistencia de imaginaciones barrocas -como la que llevó a Nicolás Mascardi a morir en un paraje perdido de la Cordillera de los Andes- en los extremos más meridionales de América $\mathrm{y}$, por último, comprender cuál fue el grado de autonomía de sujetos concretos para valerse pragmáticamente de sus supuestos y creencias.

Buenos Aires, marzo de 2020.

\section{Bibliografía citada}

Acuña, Claudia (2012). "El mundo subterráneo y la última carta de Nicolás Mascardi a su maestro Athanasius Kircher", en Acuña, Claudia (ed.), La curiosidad infinita de Athanasius Kircher. Una lectura a sus libros encontrados en la Biblioteca Nacional de Chile, Santiago de Chile: Ocho Libros, pp. 131-158.

Acuña, Claudia (2014). “La expedición del padre Nicolás Mascardi a la Patagonia: Una experiencia sobre las posibilidades y los límites del conocimiento en el siglo XVII", en Revista de Historia Social y de las mentalidades, 18 (2), pp. 33-57.

Ainsa, Fernando (1992). Historia, utopía y ficción de la Ciudad de los Césares. Metamorfosis de un mito, Madrid: Alianza Editorial.

Altic, Mirela (2017). “Jesuits at Sea: José Quiroga and José Cardiel - Two Complementary Views of Patagonia (1745-1746)", en Terrae Incognitae, 49 (2), pp. 149-173. 
Arias, Fabián (2017). "Las clasificaciones jesuitas del mundo indígena pampeano-patagónico. El caso de Tomás Falkner, SJ, 1744-1774", en Sociedades de paisajes áridos y semiáridos, 1, pp. 225-250.

Asensio, Raúl Hernández (2003). "Caciques, jesuitas y chamanes en la frontera sur de Buenos Aires (1740-1753)", en Anuario de Estudios Americanos, 60 (1), pp. 77-108.

Barcelos, Artur Henrique Franco (2013). O Mergulho no Seculum: Exploração, conquista e organização espacial jesuítica na América espanhola colonial, Porto Alegre: Animal.

Buarque de Holanda, Sérgio (1996 [1959]). Visão do Paraíso. Os motivos edênicos no descobrimento e colonização do Brasil, São Paulo: Editora Brasiliense.

Cañizares Esguerra, Jorge (2007). Cómo escribir la historia del Nuevo Mundo, México: Fondo de Cultura Económica.

Cardiel, José (1933 [1748]). Diario del viaje y misión al Río del Sauce realizado en 1748 (Guillermo Furlong \& Félix F. Outes, editores). Buenos Aires: Coni.

Cardiel, José (1956 [1747]). “Defficultades, q suelehaber en la conversion delos infieles, y medios pa vencerlas", en Milcíades Alejo Vignati (ed.), Viajeros, obras y documentos para el estudio del hombre americano. Una narración fiel de los peligros y desventuras que sobrellevó Isaac Morris, Buenos Aires: Imprenta y Casa Editora Coni, pp. 151-172.

Cargnel, Josefina G. (2009). “La Historia de la conquista en las versiones de Pedro Lozano y José Guevara. Estudios comparados de la producción escrita de la Compañía de Jesús en el siglo XVIII", en História Unisinos, 13 (3), pp. 297-307.

Certeau, Michel de (2007). "Historia de los jesuitas", en El lugar del otro. Historia religiosa y mística, Buenos Aires: Katz, pp. 169-211.

Charlevoix, Pierre François Xavier de, \& Muriel, Domingo (1916 [1757]). Historia del Paraguay, Madrid: Librería General de Victoriano Suárez.

Chartier, Roger (1992). "El mundo como representación", en El mundo como representación. Estudios sobre historia cultural, Barcelona: Gedisa, pp. 45-62.

Chartier, Roger (1996). Escribir las prácticas: Foucault, de Certeau, Marin, Buenos Aires: Manantial.

De Angelis, Pedro (ed.) (1836). Derroteros y viages a la Ciudad Encantada, ó de los Cesares. Que se creía existiese en la cordillera, al sud de Valdivia, Buenos Aires: Imprenta del Estado.

Estellé, Patricio \& Coudyoudmjian, Ricardo (1968). “La ciudad de los Césares: Origen y evolución de una leyenda. 1526-1880", en Historia, 7, pp. 283-309.

Falkner, Tomás (2003 [1774]). Descripción de la Patagonia y de las partes contiguas de la América del Sur, Buenos Aires: Taurus. 
Fraschini, Alfredo E. (ed.) (2005). Index librorum Bibliothecae Collegii Maximi Cordubensis Societatis Jesu anno 1757: Edición crítica, filológica y biobibliográfica (Vol. 1), Córdoba: Universidad Nacional de Córdoba.

Furlong, Guillermo (1938). Entre los pampas de Buenos Aires, Buenos Aires: Talleres gráficos "San Pablo".

Furlong, Guillermo (Ed.). (1953). José Cardiel, S.J. y su Carta-Relación (1747), Buenos Aires: Librería del Plata.

Furlong, Guillermo (Ed.). (1963). Nicolás Mascardi, S. J. y su Carta-Relación (1670), Buenos Aires: Ediciones Theoria.

Furlong, Guillermo (1992). Entre los tehuelches de la Patagonia, Buenos Aires: Theoria.

Gandía, Enrique de (1933). "La ciudad encantada de los Césares: Última leyenda que murió en América", en La ciudad encantada de los Césares, Buenos Aires: Librería de A. García Santos, pp. 7-53.

Gandía, Enrique de (1946). Historia crítica de los mitos y leyendas de la conquista americana. Buenos Aires: Centro Difusor del Libro.

Gorzalczany, Marisa Andrea \& Olmos Gaona, Alejandro (2006). La biblioteca jesuítica de Asunción, Buenos Aires: edición de los autores.

Grafton, Anthony, Shelford, April \& Siraisi, Nancy G. (1995). New Worlds, Ancient Texts. The Power of Tradition and the Shock of Discovery, Cambridge: Harvard University Press - The New York Public Library.

Greenblatt, Stephen (1991). Marvelous Possessions: The Wonder of the New World, Chicago: University of Chicago Press.

Guevara, José (1882 [c. 1760]). Historia de la conquista del Paraguay, Río de la Plata, y Tucumán (Andrés Lamas, editor), Buenos Aires: S. Ostwald.

Maldavsky, Aliocha (2012). Vocaciones inciertas. Misión y misioneros en la provincia jesuita del Perú en los siglos XVI y XVII, Lima: Consejo Superior de Investigaciones Científicas.

Martínez Martín, Carmen (1994). “Las reducciones de las pampas (1740-53): Aportaciones etnogeográficas al sur de Buenos Aires", en Revista Complutense de Historia de América, 20, pp. 145-168.

Martinic B., Mateo (2007). “Los Césares de la Patagonia, ¿otra fuente indígena para la leyenda o una hasta ahora desconocida creación del imaginario aónikenk?", en Magallánica, 35 (2), pp. 7-14.

Ovalle, Alonso de. (1646). Historica relación del Reyno de Chile, Roma: por Francisco Caballo. 
Perrone, Nicolás Hernán (2019). "Pedro de Angelis y la reapropiación de los saberes jesuíticos del Paraguay. Un estudio de la Colección de obras y documentos relativos a la historia antigua y moderna de las provincias del Río de la Plata (18361837)", en Illes i imperis, 21, pp. 315-337.

Romano, Antonella (2011). "La experiencia de la misión y el mapa europeo de los saberes sobre el mundo en el Renacimiento: Antonio Possevino y José de Acosta", en Wilde, Guillermo (ed.) Saberes de la conversión. Jesuitas, indígenas e imperios coloniales en las fronteras de la cristiandad, Buenos Aires: SB, pp. 133-154.

Sanchez, Jean-Pierre (1996). Mythes et légendes de la conquête de l'Amérique, Rennes: Presses universitaires de Rennes.

Saracino, María Agostina (2016). “Las Batuecas del Duque de Alba: El gobierno de los hombres y la experiencia de la conquista transatlántica en la pluma de Lope de Vega", en Gandini, María Juliana, López Palmero, Malena \& Martínez, Carolina (eds.) Prismas de la experiencia moderna: Europa, el mundo ultramarino y sus representaciones entre los siglos XVI-XVIII. Homenaje a Rogelio C. Paredes, Buenos Aires: Editorial de la Facultad de Filosofía y Letras, Universidad de Buenos Aires, pp. 121-132.

Tieffemberg, Silvia (2015). “Derroteros y viajes a la ciudad encantada de los Césares: Relatos y constelaciones", en Anales de literatura chilena, 23, pp. 13-27.

Urbina C., M. Ximena (2013). "Expediciones a las costas de la Patagonia occidental en el período colonial", en Magallánica, 41 (2), pp. 51-84.

Urbina C., M. Ximena (2017). “La expedición de John Narborough a Chile, 1670: Defensa de Valdivia, rumores de indios, informaciones de los prisioneros y la creencia en la ciudad de los Césares”, en Magallánica, 45 (2), pp. 11-36.

Urbina C., M. Ximena (2020). “La creencia en la Ciudad de los Césares desde Chiloé en tiempos del jesuita Nicolás Mascardi, 1666-1673”, en Magallánica, 48 (1), pp. 5-25.

Wilde, Guillermo (2009). Religión y poder en las misiones de guaraníes, Buenos Aires: SB.

Wilde, Guillermo (2018). “Invención, circulación y manipulación de clasificaciones en los orígenes de una antropología misionera", en Giudicelli, Christophe (ed.) Luchas de clasificación. Las sociedades indígenas entre taxonomía, memoria y reapropiación, Rosario: Prohistoria, pp. 41-77. 